\title{
Evaluation of corn hybrids performance in two locations of Goiás
}

\author{
Leandro Lopes Gomes ${ }^{1}$, Wilian Henrique Diniz Buso ${ }^{1}$, Janaina Batista Lima ${ }^{1}$, Helber Garcez \\ Matos $^{1}$, Laidson Alves Leão Junior ${ }^{1}$ \\ ${ }^{1}$ Instituto Federal Goiano, Campus Ceres, Ceres, Goiás, Brasil. E-mail: leandrolopes.agr@ outlook.com, \\ wilian.buso@ifgoiano.edu.br, jana24bl@gmail.com, helberagropecuaria@gmail.com, lalj@ outlook.com
}

Received: 27/12/2017; Accepted: 10/12/2018.

\begin{abstract}
The objective of this study was to evaluate the agronomic traits and grain yield of corn hybrids in two locations of the North Central region of Goiás. The experimental design was a randomized block, in the 17x2 factorial scheme (17 hybrids and two locations) with four replications. The locations were Itapaci and Ceres. Each plot consisted of two rows of five meters, spaced $0.50 \mathrm{~m}$ and rows were sown on the sides, which served as a border. The evaluations occurred in the two central rows, excluding $0.50 \mathrm{~m}$ at the extremities. The variables analyzed were: first ear height, plant height, stem, number of ears per plant, number of grain rows, number of grains per row, 1000 grain weight and grain yield $\left(\mathrm{kg} \mathrm{ha}^{-1}\right)$. The hybrids that showed the best conditions for plant height were DKB 290 PRO 3, DKB 290 PRO 2, DKB 310 PRO 2, DAS 2B810 PW, DKB 390 PRO 2 and AS 1633 PRO 2, with emphasis on DKB 310 PRO 2, which also showed satisfactory first ear height and stem and ear diameter. About grain yield, the hybrids MG 652 PW, AGN 30A37 PW, STATUS, DKB 310 PRO 2, AG 7098 PRO 2, MG 600 PW and IMPACTO presented highest grain yield performance in both municipalities.
\end{abstract}

Keywords: Genotypes, Grain yield, Zea mays.

\section{Avaliação do desempenho de híbridos de milho em dois municípios de Goiás}

\section{RESUMO}

Objetivou-se avaliar as características agronômicas e produtividade de grãos de híbridos de milho em dois municípios do Centro-Norte de Goiás. O delineamento experimental utilizado foi em blocos ao acaso em esquema fatorial 17x2 (17 híbridos e dois locais) com quatro repetições. Os locais foram Itapaci e Ceres. Cada parcela foi constituída de duas linhas de cinco metros, espaçadas de $0,50 \mathrm{~m}$ e foram semeadas linhas nas laterais, que serviram como bordadura. As avaliações ocorreram nas duas linhas centrais, deixando $0,50 \mathrm{~m}$ de bordadura nas extremidades. As variáveis analisadas foram: altura da primeira espiga, altura de plantas, diâmetro do colmo, número de espigas por planta, número de fileira de grãos, número de grãos por fileira, massa de mil grãos e produtividade de grãos $\left(\mathrm{kg} \mathrm{ha}^{-1}\right)$. Os híbridos que apresentaram melhores condições para a altura de plantas foram DKB 290 PRO 3, DKB 290 PRO 2, DKB 310 PRO 2, DAS 2B810 PW, DKB 390 PRO 2 e AS 1633 PRO 2, com ênfase no DKB 310 PRO 2, que também apresentou boa altura de espiga e diâmetro do colmo e espiga. Quanto à produtividade, os híbridos MG 652 PW, AGN 30A37 PW, STATUS, DKB 310 PRO 2, AG 7098 PRO 2, MG 600 PW e IMPACTO apresentaram melhor desempenho produtivo nos dois municípios.

Palavras-chave: Genótipos, Produtividade, Zea mays. 


\section{Introduction}

Corn (Zea mays) is characterized by great economic importance, both domestically and abroad, as the grain is destined to the market of animal and human nutrition, as well as the production of biofuel. Focusing on this economic importance, Brazil seeks to be among the world's leading corn exporters. The estimated corn area for the 2018/1019 harvest will be 16.7 million hectares, estimated productivity of $5,408 \mathrm{~kg} \mathrm{ha}^{-1}$. In Brazil, in the 2017/2018 harvest, 16,631 million hectares were sown with an average grain yield of $4,857 \mathrm{~kg} \mathrm{ha}^{-1}$ (Conab, 2018).

In Brazil, research in the area of genetics and biotechnology was intensified, aiming to obtain hybrids for high productivity. Hybrids were a breakthrough of the last century, especially in the aspects related to the significant increase in productivity. The existing genetic diversity allows the cultivation of hybrids in the most diverse environments, for they are cultivated from latitude $58^{\circ} \mathrm{N}$ to $40^{\circ} \mathrm{S}$, developing from sea level up to 3,800 $\mathrm{m}$ altitude (Ozelame and Andreatta, 2013).

With the emergence of new genotypes and management techniques for maize cultivation, studies have been carried out to determine the genetic material to be grown in different environments and under different edaphoclimatic conditions (Gilo et al., 2011).

Simple hybrids are more demanding and have higher productive potential than triple and double hybrids, requiring higher fertility and humidity and suitable climatic conditions to express their full potential. The growth of the production systems using technologies in the Cerrado has demanded the use of corn hybrids of better adaptation that offer greater responses to the growing environments (Cardoso et al., 2011).

The objective of this study was to evaluate agronomic traits, yield components, and corn hybrids yields in two locations of the North Central region of Goiás.

\section{Material e Methods}

The experiments were conducted in two locations, at the Fazenda Córrego do Oriente, with the following geographic coordinates: 15'20'52.82" S and 49 36'10.91" W and elevation of $573 \mathrm{~m}$, in Itapaci - GO, and at The Experimental Farm of IF Goiano, Campus Ceres, with geographic coordinates $15^{\circ} 00^{\prime} 53,62^{\prime \prime} \mathrm{S}$ and 49'29'38,69" W and elevation of $538 \mathrm{~m}$, in Ceres - GO, both areas under no-tillage system. The area was desiccated seven days before sowing with the glyphosate herbicide at the dose of $3.0 \mathrm{~L} \mathrm{ha}^{-1}$ of commercial product in both areas. In the two areas, the previous crop was soybeans. Soil samples were taken from the $0-20 \mathrm{~cm}$ layer to determine fertility levels in both areas and the results were: Itapaci $-\mathrm{pH}$ in $\mathrm{H}_{2} \mathrm{O}=$ 5.8; $\mathrm{P}=45.6 \mathrm{mg} \mathrm{dm}{ }^{-3} ;$ O.M. $=22.0 \mathrm{~g} \mathrm{dm}^{-3} ; \mathrm{K}=0.35$ $\mathrm{cmol}_{\mathrm{c}} \mathrm{dm}^{-3} ; \mathrm{Ca}=3.0 \mathrm{cmol}_{\mathrm{c}} \mathrm{dm}^{-3} ; \mathrm{Mg}=1.0 \mathrm{cmol}_{\mathrm{c}} \mathrm{dm}^{-3}$; $\mathrm{H}+\mathrm{Al}=4.2 \mathrm{cmol}_{\mathrm{c}} \mathrm{dm}^{-3} ; \mathrm{V}=65.27 \% ; \mathrm{CEC}=6.77$ $\mathrm{cmol}_{\mathrm{c}} \mathrm{dm}^{-3} ; \mathrm{m}=7.24 \%$, sand $=579 \mathrm{~g} \mathrm{~kg}^{-1}$ and clay $=$ $376 \mathrm{~kg}^{-1}$. Ceres: $\mathrm{pH}$ in $\mathrm{H}_{2} \mathrm{O}=5.7 ; \mathrm{P}=16.6 \mathrm{mg} \mathrm{dm}^{-3}$; O.M. $=17 \mathrm{~g} \mathrm{dm}^{-3} ; \mathrm{K}=0.3 \mathrm{cmol}_{\mathrm{c}} \mathrm{dm}^{-3} ; \mathrm{Ca}=2.3 \mathrm{cmol}_{\mathrm{c}}$ $\mathrm{dm}^{-3} ; \mathrm{Mg}=1.9 \mathrm{cmol}_{\mathrm{c}} \mathrm{dm}^{-3} ; \mathrm{H}+\mathrm{Al}=3.2 \mathrm{cmol}_{\mathrm{c}} \mathrm{dm}^{-3} ; \mathrm{V}$ $=57.97 \% ; \mathrm{CEC}=8.3 \mathrm{cmol}_{\mathrm{c}} \mathrm{dm}^{-3} ; \mathrm{m}=0.0 \%$, sand $=269$ $\mathrm{g} \mathrm{kg}^{-1}$ and clay $=595 \mathrm{~kg}^{-1}$.

The experimental design was randomized block in $17 \times 2$ factorial scheme, with 17 corn hybrids (AS1656 PRO 3; 14K504PW; 30F53YHR; MG 652 PW; IMPACTO; STATUS; MG 580 PW; 30A37 PW; DKB 390 PRO2; DAS 2B810 PW; AG 8780 PRO 3; DKB 310 PRO2; AS 1633 PRO 2; AG 7088 PRO 3; AG 7098; MG 600; DKB 290 PRO 3) and two locations (Itapaci and Ceres) with four replications, totaling 68 plots at each location. The traits of each hybrid are shown in Table 1. Each plot consisted of two rows of five meters, with rows sown on the sides that served as a border around the experiments. The row spacing was $0.50 \mathrm{~m}$. The evaluations were carried out in the two central rows, excluding $0.50 \mathrm{~m}$ at the ends.

Sowing in Itapaci was carried out on 11/21/2015 and in Ceres, on $12 / 18 / 2015$. In the two locations, the sowing fertilization of $20 \mathrm{~kg} \mathrm{ha}^{-1}$ of $\mathrm{N}, 150 \mathrm{~kg} \mathrm{ha}^{-1}$ of $\mathrm{P}_{2} \mathrm{O}_{5}$ and $50 \mathrm{~kg} \mathrm{ha}^{-1}$ of $\mathrm{K}_{2} \mathrm{O}$ was performed. The control of weeds occurred with the application of glyphosate + atrazine at the dose of $3.0 \mathrm{~L} \mathrm{ha}^{-1}$ of both herbicides at 20 days after sowing. Topdressing fertilization was performed when the plants had six leaves fully expanded, 22 days after sowing the crop, with $130 \mathrm{~kg}$ $\mathrm{ha}^{-1}$ of $\mathrm{N}$ (urea). The estimated final population for each hybrid was 60,000 plants ha ${ }^{-1}$.

The variables analyzed were: first ear height, plant height (randomly performed in five plants in the two central lines with a tape measure), stem diameter, according to Demétrio et al. (2008), ear diameter, ear length, number of grain rows (count of total number of grains rows in five ears randomly chosen in the two central rows of plot), number of grains per row and 1000 grain weight (weighing three samples of one thousand grains in analytical scale of precision) and grain yield $\left(\mathrm{kg} \mathrm{ha}^{-1}\right)$. The harvest was carried out in Itapaci on 04/16/2016 and in Ceres on 04/25/2016 when the plants get the physiological maturity point. The material was threshed in a mechanical thresher and then weighed for yield determination on a precision scale, with grain moisture corrected to $13 \%$.

The data were submitted to joint analysis of variance and grouped by the Scott Knott test at the 5\% level of significance. The analyses were performed using $\mathrm{R}$ software (R Development Core Team, 2010). 
Table 1. Traits of the corn hybrids sown in two locations in the North Central region of Goiás.

\begin{tabular}{ccccc}
\hline Hybrids & Grain texture & Grain color & Maturation & Hybrid type \\
\hline AS 1656 PRO3 & Semi-flint & Orange & Early & Simple \\
14K504 PW & Semi-dent & Yellow/Orange & Early & Simple \\
P 30F53 YHR & Semi-flint & Orange & Early & Simple \\
IMPACTO VIP3 & Flint & Orange & Early & Simple \\
MG 580 PW & Semi-flint & Yellow/Orange & Early & Simple \\
MG 652 PW & Semi-flint & Yellow/Orange & Early & Simple \\
DKB 390 PRO2 & Semi-flint & Yellow/Orange & Early & Simple \\
DKB 310 PRO2 & Semi-flint & Yellow/Orange & Semi-early & Simple \\
DKB 340 PRO2 & Semi-flint & Yellow/Orange & Semi-early & Simple \\
DKB 290 PRO3 & Dent & Yellow/Orange & Semi-early & Simple \\
AG 7098 PRO2 & Semi-dent & Yellow/Orange & Early & Simple \\
STATUS VIP3 & Flint & Orange & Early & Simple \\
30A37 PW & Semi-flint & Orange & Early & Simple \\
DAS 2B810 PW & Semi-flint & Orange & Early & Simple \\
AG 8780 PRO3 & Semi-dent & Yellow/Orange & Early & Simple \\
AS 1633 PRO2 & Semi-flint & Orange & Early & Simple \\
AG 7088 PRO3 & Semi-flint & Orange & Early & Simple \\
MG 600 PW & Semi-flint & Yellow/Orange & Early & Simple \\
\hline
\end{tabular}

\section{Results and Discussion}

Table 2 represents the summary of the analysis of the variance of the variables evaluated and the sources of variation. For plant height, first ear height, stem and ear diameter there was no significant interaction, and the variables were analyzed separately. There was significant interaction $(\mathrm{P}<0.05)$ between the growth locations and the hybrids tested for the variables ear length, number of grain rows, number of grains per row, 1000 grain weight and grain yield.

For plant height, first ear height and stem and ear diameter there was a difference between the locations (Table 3). In Ceres, all the parameters were superior to those of Itapaci, mainly due to the irregular distribution of the precipitations. According to Buso and Arnhold (2016), climatic factors, especially water deficit and temperature, and the genetic differences of hybrids influence their performance, promoting a reduction of plant size. For plant height, hybrids DKB 290 PRO 3, DKB 230 PRO 2, DKB 310 PRO 2, DAS 2B810 PW, DKB 390 PRO 2 and AS 1633 PRO 2 showed higher height (Table 3). This factor varies according to the genetics of the hybrids and may be important for greater reserve accumulation in the stem.

Ear height was different among hybrids, in which the hybrid DKB 310 PRO 2 presented higher height (Table 3). Very high ears can increase the rate of plant breakage by promoting a higher slope of plants. This factor is also related to the genetics of each hybrid. Silva et al. (2014) reported that differences in plant height and first ear height are also associated with the genetics of hybrids. About the stem diameter of the hybrids, AS 1656 PRO 3, DKB 310 PRO 2, AG 7088 PRO 3, AG 7098 PRO 2 and MG 600 PW presented the highest values (Table 3). Plants with larger diameter stem tend to accumulate more reserves in these structures, which contributes to the filling of grains, besides serving as support structures for the ears. Figueiredo et al. (2008) observed a reduction in the stem diameter of the plants in different corn cultivars when conducted in higher densities of plants, attributing this fact to the greater competition among the plants, increasing the lodging incidence of plants.

For ear diameter, 14K504 PW, STATUS, DKB 290 PRO 3, DKB 310 PRO 2 and AG 7088 PRO 3 hybrids reached higher values, as in Table 3 . The differences of all variables among corn hybrids were due to the genetic differences that each one presents and the way of interaction with the environment. According to Alvarez et al. (2006), it is necessary to evaluate new maize cultivars in different environments, since some of the new genotypes available on the market have a lower height and a more erect leaf architecture, being more productive in relation to older materials; thus, these hybrids can be worked with a higher population densities.

A significant interaction for ear length between the locations and corn hybrids occurred (Table 4). In Itapaci, there was no difference between hybrids for this variable. The hybrids P30F53 YHR, DAS 2B810 PW, 
AG 8780 PRO 3 and MG 600 PW reached higher ear length when grown in Ceres compared to their Itapaci performance. For the AG 7088 PRO 3 hybrid, it was verified that the largest ear length was in Itapaci, with a value of $150.50 \mathrm{~mm}$ and, in Ceres, $131.67 \mathrm{~mm}$ (Table 4). For the experiment carried out in Ceres, several hybrids presented higher ear length than in Itapaci (DAS 2B810PW (159.05 and $131.25 \mathrm{~mm}$ ),
P 30F53 HYR (167.23 and 137.0 mm), AG 8780 PRO3 $(165,45$ and $144.0 \mathrm{~mm})$ and MG $600 \mathrm{PW}$ (159.9 and $141.5 \mathrm{~mm}$, respectively), as shown in Table 4.

According to Kappes et al. (2011), the higher intraspecific competition for water, light, and nutrients in high plant populations and according to the genotype used, may lead to a decrease in the size of specific structures of maize plants, such as ears.

Table 2. Mean squares of variation sources of locations and hybrids and the interaction between locations and hybrids for agronomic traits and grain.

\begin{tabular}{|c|c|c|c|}
\hline \multirow{2}{*}{ Variables } & \multicolumn{3}{|c|}{ Sources of variation } \\
\hline & Locations & Hybrids & Locations $\mathrm{x}$ Hybrids \\
\hline Plant height & $11.1494 * *$ & $0.0909 * *$ & $0.0097^{\mathrm{ns}}$ \\
\hline First ear height & $0.6511 * *$ & $0.0669 * *$ & $0.0062^{\mathrm{ns}}$ \\
\hline Stem diameter & $250.5674 * *$ & $8.5162 * *$ & $3.9258^{\mathrm{ns}}$ \\
\hline Ear diameter & $294.8240 * *$ & $4.8331 * *$ & $2.8112^{\mathrm{ns}}$ \\
\hline Ear length & $3561.8824 * *$ & $415.3702 * *$ & $299.9066 * *$ \\
\hline Number of grain rows & $31.2576^{* *}$ & $3.9617 * *$ & $3.4208 * *$ \\
\hline Number of grains per row & $3.4208 * *$ & $19.4319 * *$ & $12.5809 * *$ \\
\hline 1000 grain weight & $9192.056^{* *}$ & $4664.171 * *$ & $2189.344 * *$ \\
\hline Grain yield & $1028390003 * *$ & $7554126^{* *}$ & $3991315^{* *}$ \\
\hline
\end{tabular}

Values followed by $(* *)$ are significant and (ns) are not significant at $5 \%$ probability by the Scott Knott test.

Table 3. Plant height, first ear height, stem diameter, ear diameter of corn hybrids in two locations.

\begin{tabular}{|c|c|c|c|c|}
\hline Locations & $\begin{array}{l}\text { Plant height } \\
\text { (m) }\end{array}$ & $\begin{array}{l}\text { First ear height } \\
\text { (m) }\end{array}$ & $\begin{array}{c}\text { Stem diameter } \\
(\mathrm{mm})\end{array}$ & $\begin{array}{c}\text { Ear diameter } \\
(\mathrm{mm})\end{array}$ \\
\hline Itapaci & $2.24 \mathrm{~b}$ & $1.25 \mathrm{~b}$ & $20.49 \mathrm{~b}$ & $46.45 \mathrm{~b}$ \\
\hline Ceres & 2.81. a & $1.39 \mathrm{a}$ & $23.20 \mathrm{a}$ & $49.39 \mathrm{a}$ \\
\hline \multicolumn{5}{|l|}{ Hybrids } \\
\hline AS1656 PRO 3 & $2.59 \mathrm{~b}$ & $1.27 \mathrm{c}$ & $22.98 \mathrm{a}$ & $47.06 \mathrm{~b}$ \\
\hline 14K504 PW & $2.54 \mathrm{~b}$ & $1.29 \mathrm{c}$ & $21.40 \mathrm{~b}$ & $49.13 \mathrm{a}$ \\
\hline P30F53 YHR & $2.55 \mathrm{~b}$ & $1.28 \mathrm{c}$ & $20.75 \mathrm{~b}$ & $47.16 \mathrm{~b}$ \\
\hline MG 652 PW & $2.45 \mathrm{c}$ & $1.28 \mathrm{c}$ & $21.62 b$ & $47.80 \mathrm{~b}$ \\
\hline MG 580 PW & $2.34 \mathrm{~d}$ & $1.24 \mathrm{~d}$ & $20.89 \mathrm{~b}$ & $47.38 \mathrm{~b}$ \\
\hline AGN 30A37 PW & $2.32 \mathrm{~d}$ & $1.19 \mathrm{~d}$ & $20.82 \mathrm{~b}$ & $47.90 \mathrm{~b}$ \\
\hline IMPACTO & $2.47 \mathrm{c}$ & $1.33 \mathrm{c}$ & $20.97 \mathrm{~b}$ & $46.75 \mathrm{~b}$ \\
\hline STATUS & $2.52 \mathrm{~b}$ & $1.34 \mathrm{c}$ & $21.86 \mathrm{~b}$ & $48.90 \mathrm{a}$ \\
\hline DKB 290 PRO 3 & $2.59 \mathrm{~b}$ & $1.38 \mathrm{~b}$ & $21.93 \mathrm{~b}$ & $49.54 \mathrm{a}$ \\
\hline DKB 390 PRO 2 & $2.67 \mathrm{a}$ & $1.45 \mathrm{~b}$ & $21.98 \mathrm{~b}$ & $47.53 \mathrm{~b}$ \\
\hline DAS 2B810 PW & $2.63 \mathrm{a}$ & $1.29 \mathrm{c}$ & $20.07 \mathrm{~b}$ & $47.58 \mathrm{~b}$ \\
\hline AG 8780 PRO 3 & $2.39 \mathrm{~d}$ & $1.17 \mathrm{~d}$ & $22.00 \mathrm{~b}$ & $47.78 \mathrm{~b}$ \\
\hline DKB 310 PRO 2 & $2.67 \mathrm{a}$ & $1.53 \mathrm{a}$ & $23.90 \mathrm{a}$ & $48.32 \mathrm{a}$ \\
\hline AS 1633 PRO 2 & $2.62 \mathrm{a}$ & $1.35 \mathrm{c}$ & $21.58 \mathrm{~b}$ & $48.06 \mathrm{~b}$ \\
\hline AG 7088 PRO 3 & $2.52 \mathrm{~b}$ & $1.40 \mathrm{~b}$ & $22.52 \mathrm{a}$ & $48.79 \mathrm{a}$ \\
\hline AG 7098 PRO 2 & $2.58 \mathrm{~b}$ & $1.42 \mathrm{~b}$ & $23.65 \mathrm{a}$ & $47.48 \mathrm{~b}$ \\
\hline MG 600 PW & $2.32 \mathrm{~d}$ & $1.29 \mathrm{c}$ & $22.43 \mathrm{a}$ & $47.49 \mathrm{~b}$ \\
\hline $\mathrm{CV}(\%)$ & 4.04 & 7.84 & 7.21 & 3.46 \\
\hline
\end{tabular}

Averages followed by the same letter in the columns belong by the same group by Scott Knott test at $5 \%$ probability. 
Table 4. The interaction between hybrids and locations for ear length (mm).

\begin{tabular}{|c|c|c|}
\hline \multirow{2}{*}{ Hybrids } & \multicolumn{2}{|c|}{ Locations } \\
\hline & Itapaci & Ceres \\
\hline AS1656 PRO 3 & $149.75 \mathrm{aA}$ & $167.50 \mathrm{aA}$ \\
\hline 14K504 PW & $153.25 \mathrm{aA}$ & $151.87 \mathrm{aB}$ \\
\hline P30F53 YHR & $137.00 \mathrm{bA}$ & $167.23 \mathrm{aA}$ \\
\hline MG 652 PW & $146.00 \mathrm{aA}$ & $159.75 \mathrm{aA}$ \\
\hline MG 580 PW & $138.00 \mathrm{aA}$ & $145.60 \mathrm{aB}$ \\
\hline AGN 30A37 PW & $151.25 \mathrm{aA}$ & $156.85 \mathrm{aA}$ \\
\hline IMPACTO & $138.25 \mathrm{aA}$ & $137.50 \mathrm{aB}$ \\
\hline STATUS & $141.25 \mathrm{aA}$ & $154.42 \mathrm{aA}$ \\
\hline DKB 290 PRO 3 & $140.75 \mathrm{aA}$ & $151.85 \mathrm{aB}$ \\
\hline DKB 390 PRO 2 & $146.25 \mathrm{aA}$ & $140.80 \mathrm{aB}$ \\
\hline DAS 2B810 PW & $131.25 \mathrm{bA}$ & $159.05 \mathrm{aA}$ \\
\hline AG 8780 PRO 3 & $144.00 \mathrm{bA}$ & $165.45 \mathrm{aA}$ \\
\hline DKB 310 PRO 2 & $157.50 \mathrm{aA}$ & $170.97 \mathrm{aA}$ \\
\hline AS 1633 PRO 2 & $131.50 \mathrm{aA}$ & $145.75 \mathrm{aB}$ \\
\hline AG 7088 PRO 3 & $150.50 \mathrm{aA}$ & $131.67 \mathrm{bB}$ \\
\hline AG 7098 PRO 2 & $143.00 \mathrm{aA}$ & $148.82 \mathrm{aB}$ \\
\hline MG 600 PW & $141.50 \mathrm{bA}$ & $159.90 \mathrm{aA}$ \\
\hline
\end{tabular}
test at $5 \%$ probability.

There was significant interaction for the number of grain rows per ear between hybrids and locations (Table 5). The hybrids 14K504 PW, P30F53 YHR, STATUS, DKB 290 PRO 3, AG 7088 PRO 3 and AG 7098 PRO 2 presented the highest number of grain rows in Ceres when compared to Itapaci. In Itapaci, hybrids did not present statistical difference for this variable; in Ceres, the DAS 2B810 PW and AG 7088 PRO3 hybrids presented the highest number of grain rows (17.83 and 18.25 grain rows per ear, respectively). The others obtained smaller numbers of rows of grains, as presented in Table 5.

This variable is important because it can exert a direct influence on hybrids productivity; thus, as the number of grain rows increases, there are more grains per ear, resulting in increased grain yield. The number of grain rows may have contributed to the grain yield of the DAS 2B810 PW hybrid (Table 8); the same was not observed for AG 7088 PRO3 (Table 8), a fact that can be explained by the lower specific mass of the grains, according to Table 7.

According to Modolo et al. (2010) when working with four hybrids using a spacing of $0.45 \mathrm{~m}$ between rows, no difference was found for the number of rows per ear. When using hybrids with upright leaf architecture and reducing the spacing of 0.90 for the currently used ones from 0.45 to $0.50 \mathrm{~m}$, this management has contributed to increase the number of grain rows and to grain yield gains.

Table 6 shows the interaction between hybrids and locations for the number of grains per row. The hybrids AS1656 PRO 3, 14K504 PW, P30F53 YHR, MG 652 PW, MG 580 PW, AGN 30A37 PW, DAS 2B810 PW, DKB 310 PRO 2, AS 1633 PRO 2, AG 7098 PRO 2 and MG 600 PW presented the highest number of grains per row in Ceres, and the others presented lower averages. In Itapaci, all hybrids presented statistically the same number of grains per row (Table 6).

Hybrids MG 580 PW, IMPACT, STATUS, DKB 290 PRO 3, DKB 390 PRO 2, AG 8780 PRO 3, DKB 310 PRO 2 and AG 7088 PRO 3 were statistically similar for the number of grains per row at the two growing sites; the others presented higher averages in the Ceres (Table 6). This yield component can significantly influence grain yield because hybrids with more rows per ear tend to be more productive, as can be seen in Table 8 , which shows that all those that presented the highest number of grains per row in Ceres also presented higher grain yield (Table 8).

In the study carried out by Modolo et al. (2010) evaluating the hybrids DKB 240, P30R50 and SG 6010, no difference was found in the number of grains per row among the hybrids. According to the same authors, spacings above $0.70 \mathrm{~m}$ can lead to an increase in the 
number of grains per row, and in smaller spacings, this variable may be smaller.

There was an interaction between hybrids $\mathrm{x}$ locations for the 1000 grain weight (Table 7). The hybrid AG 7088 PRO 3 presented larger 1000 grain weight in Itapaci $(351,31 \mathrm{~g})$, however, in Ceres, presented the lowest grain mass $(280,28 \mathrm{~g})$. The hybrids DKB 310 PRO 2 and AS 1633 PRO 2 reached a larger 1000 grain weight in Ceres when compared to their performance in Itapaci, according to Table 7.

In Itapaci, the hybrids AS1633 PRO 3, 14K504 PW, P30F53 YHR, MG 652 PW, AGN 30A37 PW, DAS 2B810 PW, AS 1633 PRO 2, Ag 7098 PRO 2 and MG $600 \mathrm{PW}$ presented the lowest 1000 grain weight compared to the others. In the Ceres cultivation, the AS1656 PRO 3, DKB 290 PRO 3, AG 8087 PRO 3, DKB 310 PRO 2, AS 1633 PRO 2 and Ag 7098 PRO 2 hybrids presented the highest means of 1000 grain weight about the others (Table 7).

According to Kvitschal et al. (2010), differences occurring in the 1000 grain weight are related to grain texture, and hybrids with a grain of semi-flint and flint texture have a higher mass. In this way, the same may have occurred in the present work.

For grain yield, the interaction between hybrids and localities occurred (Table 8). All hybrids showed higher productivity in Ceres than in Itapaci, which may have occurred due to the water deficit in Itapaci at the beginning of the crop development, in November of 2015 .

In Itapaci, the most productive hybrids were $\mathrm{MG}$ 652 PW, AGN 30A37 PW, IMPACTO, STATUS, DKB 310 PRO 2, AG 7098 PRO 2 and MG 600 PW, as presented in Table 8. In conditions of water deficit, these hybrids presented superior performance than others.

In Ceres, the hybrids with the highest grain yield were P30F53 YHR, MG 652 PW, MG 580 PW, AGN 30A37 PW, STATUS, DKB 290 PRO 3, DAS 2B810 PW, AG 8780 PRO 3, DKB 310 PRO 2, AG 7098 PRO 2 and MG 600 PW (Table 8). With the increased availability of corn cultivars, the uncertainties of the producer as to the choice of genotypes are also increased. The use of hybrids that best adapt to growing conditions may provide higher grain yield (Silva et al., 2015).

According to Marchão et al. (2005), the introduction of hybrids with high grain yield potential, the increase in the use of fertilizers, the development of new herbicides and the adoption of the no-tillage system have allowed the adoption of higher plant populations, whose main objective is to increase the grain yield.

Table 5. The interaction between hybrids and locations for the number of grain rows.

\begin{tabular}{ccc}
\hline Hybrids & \multicolumn{2}{c}{ Locations } \\
\cline { 2 - 3 } & Itapaci & Ceres \\
\hline AS1656 PRO 3 & $15.70 \mathrm{aA}$ & $15.70 \mathrm{aC}$ \\
14K504 PW & $14.60 \mathrm{bA}$ & $15.70 \mathrm{aC}$ \\
P30F53 YHR & $14.60 \mathrm{bA}$ & $16.50 \mathrm{aC}$ \\
MG 652 PW & $15.20 \mathrm{aA}$ & $14.70 \mathrm{aD}$ \\
MG 580 PW & $15.50 \mathrm{aA}$ & $16.30 \mathrm{aC}$ \\
AGN 30A37 PW & $15.20 \mathrm{aA}$ & $15.20 \mathrm{aD}$ \\
IMPACTO & $16.20 \mathrm{aA}$ & $16.30 \mathrm{aC}$ \\
STATUS & $15.50 \mathrm{bA}$ & $17.50 \mathrm{aB}$ \\
DKB 290 PRO 3 & $15.40 \mathrm{bA}$ & $16.95 \mathrm{aB}$ \\
DKB 390 PRO 2 & $15.80 \mathrm{aA}$ & $17.00 \mathrm{aB}$ \\
DAS 2B810 PW & $16.60 \mathrm{aA}$ & $17.80 \mathrm{aA}$ \\
AG 8780 PRO 3 & $15.95 \mathrm{aA}$ & $16.20 \mathrm{aC}$ \\
DKB 310 PRO 2 & $15.80 \mathrm{aA}$ & $16.80 \mathrm{aB}$ \\
AS 1633 PRO 2 & $15.30 \mathrm{aA}$ & $14.50 \mathrm{aD}$ \\
AG 7088 PRO 3 & $16.25 \mathrm{bA}$ & $18.25 \mathrm{aA}$ \\
AG 7098 PRO 2 & $15.10 \mathrm{bA}$ & $16.80 \mathrm{aB}$ \\
MG 600 PW & $15.70 \mathrm{aA}$ & $15.10 \mathrm{aD}$ \\
\hline CV (\%) & &
\end{tabular}

$$
\mathrm{CV}(\%)
$$

6.19

Averages followed by the same lowercase letter in the lines and uppercase in the columns belong by the same group by Scott Knott test at $5 \%$ probability. 
Table 6. The interaction between hybrids and locations for the number of grains per row.

\begin{tabular}{cll}
\hline Hybrids & & Locations \\
\cline { 2 - 3 } & Itapaci & Ceres \\
\hline AS1656 PRO 3 & $30.45 \mathrm{bA}$ & $34.05 \mathrm{aA}$ \\
14K504 PW & $28.60 \mathrm{bA}$ & $33.05 \mathrm{aA}$ \\
P30F53 YHR & $27.55 \mathrm{bA}$ & $34.60 \mathrm{aA}$ \\
MG 652 PW & $28.79 \mathrm{bA}$ & $33.85 \mathrm{aA}$ \\
MG 580 PW & $30.65 \mathrm{aA}$ & $33.20 \mathrm{aA}$ \\
AGN 30A37 PW & $29.80 \mathrm{bA}$ & $35.10 \mathrm{aA}$ \\
IMPACTO & $29.20 \mathrm{aA}$ & $28.70 \mathrm{aB}$ \\
STATUS & $28.65 \mathrm{aA}$ & $28.20 \mathrm{aB}$ \\
DKB 290 PRO 3 & $27.20 \mathrm{aA}$ & $28.25 \mathrm{aB}$ \\
DKB 390 PRO 2 & $28.50 \mathrm{aA}$ & $29.05 \mathrm{aB}$ \\
DAS 2B810 PW & $29.20 \mathrm{bA}$ & $34.60 \mathrm{aA}$ \\
AG 8780 PRO 3 & $29.15 \mathrm{aA}$ & $30.47 \mathrm{aB}$ \\
DKB 310 PRO 2 & $30.05 \mathrm{aA}$ & $32.90 \mathrm{aA}$ \\
AS 1633 PRO 2 & $26.75 \mathrm{bA}$ & $29.95 \mathrm{aB}$ \\
AG 7088 PRO 3 & $31.22 \mathrm{aA}$ & $29.05 \mathrm{aB}$ \\
AG 7098 PRO 2 & $28.90 \mathrm{bA}$ & $33.15 \mathrm{aA}$ \\
MG 600 PW & $30.10 \mathrm{bA}$ & $34.40 \mathrm{aA}$ \\
\hline CV (\%) & & 7.10 \\
\hline
\end{tabular}

Averages followed by the same lowercase letter in the lines and uppercase in the columns belong by the same group by Scott Knott test at $5 \%$ probability.

Table 7. The interaction between hybrids and locations for 1000 grain weight $(\mathrm{g})$.

\begin{tabular}{ccc}
\hline Hybrids & & Locations \\
\cline { 2 - 3 } & Itapaci & Ceres \\
\hline AS1656 PRO 3 & $317.78 \mathrm{aA}$ & $367.15 \mathrm{aA}$ \\
14K504 PW & $309.88 \mathrm{aB}$ & $309.88 \mathrm{aB}$ \\
P30F53 YHR & $342.46 \mathrm{aA}$ & $305.34 \mathrm{aB}$ \\
MG 652 PW & $291.95 \mathrm{aB}$ & $315.93 \mathrm{aB}$ \\
MG 580 PW & $302.60 \mathrm{aB}$ & $310.26 \mathrm{aB}$ \\
AGN 30A37 PW & $315.81 \mathrm{aA}$ & $329.46 \mathrm{aB}$ \\
IMPACTO & $296.94 \mathrm{aB}$ & $309.02 \mathrm{aB}$ \\
STATUS & $321.63 \mathrm{aA}$ & $333.96 \mathrm{aB}$ \\
DKB 290 PRO 3 & $360.45 \mathrm{aA}$ & $388.41 \mathrm{aA}$ \\
DKB 390 PRO 2 & $282.05 \mathrm{aB}$ & $312.94 \mathrm{aB}$ \\
DAS 2B810 PW & $265.55 \mathrm{aB}$ & $306.83 \mathrm{aB}$ \\
AG 8780 PRO 3 & $322.31 \mathrm{aA}$ & $344.98 \mathrm{aA}$ \\
DKB 310 PRO 2 & $302.53 \mathrm{bB}$ & $356.85 \mathrm{aA}$ \\
AS 1633 PRO 2 & $333.09 \mathrm{bA}$ & $392.18 \mathrm{aA}$ \\
AG 7088 PRO 3 & $351.31 \mathrm{aA}$ & $280.27 \mathrm{bB}$ \\
AG 7098 PRO 2 & $320.50 \mathrm{aA}$ & $344.96 \mathrm{aA}$ \\
MG 600 PW & $279.11 \mathrm{aB}$ & $306.56 \mathrm{aB}$ \\
\hline
\end{tabular}

$\mathrm{CV}(\%) \quad 10.78$

Averages followed by the same lowercase letter in the lines and uppercase in the columns belong by the same group by Scott Knott test at $5 \%$ probability. 
Table 8. The interaction between hybrids and locations for grain yield $\left(\mathrm{kg} \mathrm{ha}^{-1}\right)$.

\begin{tabular}{ccc}
\hline Hybrids & \multicolumn{2}{c}{ Locations } \\
\cline { 2 - 3 } & Itapaci & Ceres \\
\hline AS1656 PRO 3 & $4.47 \mathrm{bB}$ & $\mathrm{aB}$ \\
14K504 PW & $5.60 \mathrm{bB}$ & $10.87 \mathrm{aB}$ \\
P30F53 YHR & $5.49 \mathrm{bB}$ & $12.16 \mathrm{aA}$ \\
MG 652 PW & $6.64 \mathrm{bA}$ & $11.78 \mathrm{aA}$ \\
MG 580 PW & $5.70 \mathrm{bB}$ & $12.15 \mathrm{aA}$ \\
AGN 30A37 PW & $7.92 \mathrm{bA}$ & $11.54 \mathrm{aA}$ \\
IMPACTO & $7.80 \mathrm{bA}$ & $10.35 \mathrm{aB}$ \\
STATUS & $8.18 \mathrm{bA}$ & $12.99 \mathrm{aA}$ \\
DKB 290 PRO 3 & $4.91 \mathrm{bB}$ & $13.00 \mathrm{aA}$ \\
DKB 390 PRO 2 & $4.48 \mathrm{bB}$ & $10.06 \mathrm{aB}$ \\
DAS 2B810 PW & $4.45 \mathrm{bB}$ & $12.34 \mathrm{aA}$ \\
AG 8780 PRO 3 & $6.12 \mathrm{bB}$ & $12.73 \mathrm{aA}$ \\
DKB 310 PRO 2 & $7.32 \mathrm{bA}$ & $12.40 \mathrm{aA}$ \\
AS 1633 PRO 2 & $5.39 \mathrm{bB}$ & $11.31 \mathrm{aB}$ \\
AG 7088 PRO 3 & $6.15 \mathrm{bB}$ & $11.16 \mathrm{aB}$ \\
AG 7098 PRO 2 & $8.24 \mathrm{bA}$ & $12.24 \mathrm{aA}$ \\
MG 600 PW & $7.08 \mathrm{bA}$ & $12.89 \mathrm{aA}$ \\
\hline CV (\%) & & 16.73 \\
\hline
\end{tabular}

Averages followed by the same lowercase letter in the lines and uppercase in the columns belong by the same group by Scott Knott test at $5 \%$ probability.

\section{Conclusions}

The hybrids had different behavior at the two planting sites.

Among the evaluated hybrids, MG 652 PW, AGN 30A37 PW, IMPACTO, STATUS, DKB 310 PRO 2, AG 7098 PRO 2 and MG 600 PW had the best results in Itapaci and Ceres.

\section{Bibliographic references}

Alvarez, C.G.D., Pinho, R.G., Borges, I.D. 2006. Avaliação de características agronômicas e de produção de forragens e grãos de milho em diferentes densidades de semeadura e espaçamentos entre linhas. Ciência e Agrotecnologia, Lavras, 30, 402-408.

Buso, W.H.D., Arnhold, E. 2016. Evaluation of corn hybrids under contrasting water availability conditions. Revista Caatinga, Mossoró, 29, 927-934.

Cardoso, M.J., Carvalho, H.W.L., Pacheco, C.A.P., Rocha, L.M.P., Guimarães, L.J.M., Guimarães, P.E.O., Oliveira, I.R. 2011. Rendimento de Grãos de Híbridos Comerciais de Milho nas Regiões Sul, Centro-Sul e Leste Maranhense. Embrapa MeioNorte. Teresina. 8p. Comunicado Técnico, 228. Disponível em: https://ainfo.cnptia.embrapa.br/digital/bitstream/item/54748/1/Ren dimento-graos.pdf. Acesso em: 17/10/2018.

Conab. Companhia Nacional de Abastecimento. 2018. Acompanhamento da safra brasileira de grãos. 6, 74-79. Disponível em: https://www.conab.gov.br/info-agro/safras. Acesso em: 17/10/2018.
Demétrio, C.S., Fornasieri Filho, D., Cazetta, J.O., Cazetta, D.A. 2008. Desempenho de híbridos de milho submetidos a diferentes espaçamentos e densidades populacionais. Pesquisa Agropecuária Brasileira, Brasília, 43, 1691-1697.

Figueiredo, E., Ascencio. F., Savio, G.M. 2008 Características agronômicas de três cultivares de milho sob quatro populações de plantas. Revista Científica Eletrônica de Agronomia, Garça, 7, 1-6. Disponível em: http://faef.revista.inf.br/imagens_arquivos/arquivos_destaque/t cPXFoE6i7NgE4L_2013-5-3-15-26-46.pdf > Acesso em $17 / 10 / 2018$

Gilo, E.G., Silva Junior, C.A., Torres, F.E., Nascimento E.S., Lourenção, A.S. 2011. Comportamento de híbridos de milho no cerrado sul-matogrossense, sob diferentes espaçamentos entre linhas. Bioscience Journal, Uberlândia, 27, 908-914.

Kappes, C., Andrade, J.A.C., Arf, O., Oliveira, Â.C., Arf, M.V., Ferreira, J.P. 2011. Desempenho de híbridos de milho em diferentes arranjos espaciais de plantas. Bragantia, Campinas, 70, 334-343.

Kvitschal, M.C., Martine, E., Vidigal Filho, P.S., Vidigal, M.C.G., Scapim, C.A. 2010. Arranjo de plantas e produção de dois híbridos simples de milho. Revista Ciência Agronômica, Fortaleza, 41, 122-131.

Marchão, R.L., Brasil, E M., Duarte, J.B., Guimarães, C.M., Gomes, J.A. 2005. Densidade de plantas e características agronômicas de híbridos de milho sob espaçamento reduzido entre linhas. Pesquisa Agropecuária Tropical, Goiânia, 35, 93101. 
Modolo, A.J., Carnieletto, R., Kolling, E.M., Trogello, E., Sgarbossa, M. 2010. Desempenho de híbridos de milho na Região Sudoeste do Paraná sob diferentes espaçamentos entre linhas. Revista Ciência Agronômica, Fortaleza, 41, 435-441.

Ozelame, O.; Andreatta, T. 2013. Avaliação de desempenho técnico e econômico: um estudo comparativo entre o milho híbrido e o milho Bt. Custos e @ gronegócio on line, Recife, 9, 210-232.

R Development Core Team. 2010. R: A language and environment for statistical computing. $\mathrm{R}$ Foundation for Statistical Computing, Vienna, Austria. ISBN 3-900051-07-0, URL http://www.R-project.org. Acesso em 17/10/2018.
Silva, A.F., Schoninger, E.L., Caione, G., Kuffel, C., Carvalho, M.A.C. 2014. Produtividade de híbridos de milho em função do espaçamento e da população de plantas em sistema de plantio convencional. Revista Brasileira de Milho e Sorgo, Sete Lagoas, 13, 162-173.

Silva, A.G., Francischini, R., Martins, P.D.S. 2015. Desempenho agronômico e econômico de cultivares de milho na safrinha. Revista Agrarian, Dourados, 8, 1-11. 